UDC: 618.3:612.017.1:618.177-089.888.11

\title{
NUMBERS OF NATURAL KILLERS LYMPHOCYTES DO NOT DETERMINE THEIR CYTOTOXICITY
}

\section{B. V. Dons'koi}

Institute of Pediatrics, Obstetrics and Gynecology, NAMS of Ukraine 8, Platon Mayboroda St., 04050 Kyiv, Ukraine e-mail: boris_donskoy@ukr.net

Dons'koi B. V. Numbers of natural killers lymphocytes do not determine their cytotoxicity. Studia Biologica, 2019: 13(2); 11-20 • DOI: https://doi.org/10.30970/sbi.1302.599

Natural killer's cytotoxicity test accepted as a "gold standard" for measuring natural killer's function. However it is methodologically difficult for introduction in routine diagnostic practice. In our previous study, we showed a prognostic clinical significance of immune parameters when they are out of a optimal range (accentuated). In contrast, balanced "not accentuated" immune parameters associated with favorable clinical outcome. In this study, we attempted to explain the disparity of the accentuated but immunologically normal natural killer's parameters that might serve as negative clinical prognostical biomarkers indicative of failed pregnancies. We have analyzed number natural killers \%, their cytotoxicity, and their reciprocal correlation in 8,664 patients with reproductive failures. We found an elevated natural killer's cytotoxicity in a significant part of infertility population. An elevated natural killer's cytotoxicity was significantly more often registered in patient with multiple reproductive failures $(41.6 \%)$ detected in patients with uncomplicated infertility $(18.7 \%)$. In the entire clinical population, \% of natural killers correlates with their cytotoxicity. Interestingly, we found this correlation was strongly dependent on status of natural killer's levels. Natural killer's \% - natural killer's cytotoxicity correlation was strongest $(r=0.2021, p<0.0001)$ in patients' group with high amount of natural killers \% (> 17.5\%). Patients with amount of natural killers \% between 15-17.5\% manifested lower but significant correlation of natural killer's \% - natural killer's cytotoxicity $(r=0.1213$, $p=0.0155)$. Additionally, a significant correlation ( $r=0.2689, p<<0.0001)$ between natural killer's \% and natural killer's cytotoxicity was observed in patients group with natural killer's levels of $<7 \%(1.7-7.3 \%)$. While, patient groups with natural killer's \% (7.3-15\%) did not demonstrate correlation of natural killer's \% - natural killer's cytotoxicity. Consistent with our hypothesis, the "balanced zone" of natural killer's \% is tightly controlled and, thus, does not correlate directly with cytotoxicity. In contrast, the "accentuated zones" of natural killer's \% escape this control and directly affected cytotoxicity.

() 2019 B. V. Dons'koi; Published by the Ivan Franko National University of Lviv on behalf of Біологічні Студії / Studia Biologica. This is an Open Access article distributed under the terms of the Creative Commons Attribution License (http://www.budapestopenaccessinitiative.org/ and Creative Commons Attribution 4.0 License), which permits unrestricted reuse, distribution, and reproduction in any medium, provided the original work is properly cited.

ISSN 1996-4536 (print) • ISSN 2311-0783 (on-line) • Біологічні Студії / Studia Biologica • 2019 • Том 13/№2 • С. 11-20 
Keywords: natural killer lymphocytes, cytotoxicity, immune accentuation, in vitro fertilization failure, recurrent miscarriages

\section{INTRODUCTION}

Natural killer cells (NK cells) are a subset of non-B, non-T peripheral blood lymphocytes that play a crucial role in the human innate immune responses [34]. NK cells represent an "evolutionary bridge" between innate and adaptive immunity [29]. They mediate a cell contact-dependent cytolysis of target cells, including those expressing foreign major histocompatibility complex (MHC) molecules, immunoglobulin-bound antigens, virally infected cells, and tumor cells. The function of NK cells is important for clearance of tumor cells [19] for the removal of immunoglobulin-bound antigens, and for the control of viral infections [20].

The role of NK cells in reproductive processes, such as implantation, trophoblast invasion, and spiral artery remodeling, is important but still poorly understood [23]. The accumulating evidence links elevation NK cells with unfavorable pregnancy outcomes in women [1, 3, 8]. NK function are decreased in healthy pregnant women [17], and individuals with primary immune deficiencies. Recent progress in development of convenient methods for quantitative and functional assessment of NK cells might help defining their role in reproductive development and other clinically important mechanisms. For example, activity of NK cells has been established as an important indicator for predicting patient outcomes in certain pathologies [13, 15, 17, 30].

Peripheral blood NK lymphocytes belong to highly heterogeneous population of cells that differ in expression of surface ligands, a repertoire of KIR receptors, ability to secrete cytokines, and cytotoxic responses. All these NK cells share the ability to express CD56 in the absence of CD3 [9, 21].The heterogeneity of NK subsets is a major contributor to their multi-functionality. This population is named after the cytotoxic reaction measured by the NK assay against HLA-negative K562 cell line, yet only a part of NK cells manifested cytotoxicity. In previous study, we demonstrated that only a subset of peripheral blood NK lymphocytes is able to respond to the K562 cells and only a fraction of this subset determines levels of NK cytotoxicity of the entire population [10]. The amount of active NK cells vary from individual to individual and their function can be easily modulated. The amount of these cells tightly correlates with actual NK cytotoxicity [11]. We also showed that balanced "optimal" counts of this fraction strongly correlated with a successful embryo implantation in IVF stimulation cycle. Whereas a misbalance of NK activity (decreased or increased active NK counts) negatively impacts the embryo implantation in IVF patients [14]. Interestingly, total NK cell counts did not correlate with such clinical outcomes. Instead, NK quantity seemed to convert to NKc indirectly via a functional subset of active NK cells - "the NK activity coefficient".

In this investigation, we analyzed correlation associations between NK cytotoxicity and NK frequency and its dependence upon NK cytotoxicity and NK lymphocytes levelsstatus.

\section{MATERIALS AND METHODS}

Study design. In a retrospective study, laboratory data of observation of 4,886 women that underwent routine immunology investigation after IVF failure or pregnancy failure were analyzed. Immunologic investigation was conducted March 2008 - October 2018. Peripheral blood was investigated 1-3 months after last IVF cycle or 3-6 months after last pregnancy failure. Patients were under 39 years (average 31.2), and had at

ISSN 1996-4536 (print) • ISSN 2311-0783 (on-line) • Біологічні Студії / Studia Biologica • 2019 • Том 13/№2 • С. 11-20 
least 1 incidence of the idiopathic IVF failure (average 2.32) or at least 1 incidence of the idiopathic first trimester pregnancy failure (average 2.04). Patients had no supplemental treatment with immunoglobulins or corticosteroids last 3 months. None of patients had active autoimmune disease or autoimmune disease in history. None of patients had active infection during at least 3 weeks. All patient signed an informed consent form before being enrolled in the study (approved by the biomedical ethics committee of Institute of Pediatrics, Obstetrics and Gynecology, National Academy of Medical Sciences of Ukraine (N 6 17/12/2012) and Clinical immunology and allergology committee of Ministry of Health (N 11 14/02/2013) according to WMA Declaration of Helsinki). Peripheral venous blood samples were drawn by venipuncture for Immunological studies (NK frequency and NK cytotoxicity) that were carried out in the Laboratory of Immunology, Institute of Paediatrics, Obstetrics and Gynaecology of the National Academy of Medical Sciences of Ukraine (Kyiv, Ukraine).

For study of NK cytotoxicity distribution, laboratory data of 9,535 individuals from similar clinical group were analyzed. All investigations were performed in $5 \mathrm{~h}$ period after blood samples were drawn.

Flow cytometry of lymphocyte subsets. Lymphocyte subsets were identified by three-color flow cytometry of lymphocytes in erythrocyte-lysing whole blood staining by FITC-, PE- or PE-Cy5-conjugated monoclonal antibodies (BD Bioscience, San Jose, USA). Stained samples were lysed, washed and analyzed by FACScan flow cytometer using CellQuest software (BD Bioscience, San Jose, USA). Number of NK lymphocytes was calculated as \% of CD3-CD56+ lymphocytes (include CD56++ subsets).

NK cytotoxicity assays. Briefly, a total $2 \times 10^{6} \mathrm{PBL}$ of were purified from peripheral blood of patients by Histopaque1077 (Sigma) gradient and washed by the PBS. Flow cytometry at NK cytotoxicity assay (FCA) used in actual study was described previously [11]. We used CMFDA (Molecular Probes, Eugene, Oreg. USA) labeling for K562 cells. Dead cells observed after $4 \mathrm{~h}$ incubation, were labeled by the propidium iodide. Less than $5 \%$ spontaneous lysis of target cells was observed. We used $50 \%$ permeabelized K562 culture for targets-gate correction. $100 \mu \mathrm{L}$ of target cells were permeabelized by $50 \mu \mathrm{L}$ ethanol (96\%). After $10 \mathrm{sec}$ wortexing, $100 \mu \mathrm{L}$ of PBS, $100 \mu \mathrm{L}$ of unaffected targets were added. The obtained suspension consisted of $50 \%$ alive and $50 \%$ permeable cell. Individual cytotoxic activity was calculated as cytotoxicity \% (ET ratio 15/1 as average from levels at 20/1 and 10/1). Inta-laboratory normal levels was obtained of $90 \% \mathrm{Cl}$ calculated for 74 healthy fertile women with a subsequent normal pregnancy development [3].

Statistical analysis. The statistical analysis of the results was performed using Fisher's Exact Test (unpaired, non-parametric, two-sided $P$ value) and the Spearman and Pearson correlations (In Stat version 3.0 for Windows Graph Pad Software Inc., San Diego, CA, USA).

\section{RESULTS AND DISCUSSION}

Distribution of values. We analyzed a distribution of NK lymphocytes levels in 4,886 patients and determined that the average content was $12 \%$, typical for healthy Caucasian women $[16,27]$. Only $1.9 \%$ of patients had NK levels $>26.1 \%$; and $4.6 \%$ had NK levels < $4.8 \%$ (Fig. 1, A). According to clinical reference values [3, 4, 5] for patients with favorable implantation and pregnancy prognosis (5.5-21\%) a decreased NK\% was observed in $5.1 \%$ patients and increased NK \% - in $6.2 \%$ of the investigated patient population.

ISSN 1996-4536 (print) • ISSN 2311-0783 (on-line) • Біологічні Студії / Studia Biologica • 2019 • Том 13/№2 • C. 11-20 
NKc and NKc average levels were also comparable to results published by other groups [7, 17]. Distribution of both have a notable trend towards increased, as well as decreased values. According to our clinical references for patients with favorable implantation and pregnancy prognosis $[3,4,5]$, we showed that $13.1 \%$ of patients have a decreased NKc, whereas, $19.4 \%$ patients had increased NKc levels (Fig 1, B). Elevated NKc was registered in patients with multiple reproductive failures (IVF failures of pregnancy failures), significantly more often $41.6 \%$ compared to patients with uncomplicated previous $(24.4 \%)$ and secondary infertility $(18.7 \%)$, as well as compared to patients with only one incidence of pregnancy failure.

Correlations. Consistently with our previous reports [11] a the frequency of NK lymphocytes in the whole clinical population strongly correlated with NK cytotoxicity $(r=0.447, p<0.0001)$ (Fig. 2, A). We did not find a significant correlation between NK counts and NK cytotoxicity in the group of patients with "normal NK levels". In contrast, this correlation was strong in groups of patients with decreased or increased NK frequency. To investigate this phenomenon, we divided the population into groups $(n=700)$ according to the individual NK-lymphocyte counts (Fig. 2, B). We found strong NK \%-NKc correlation $(r=0.167, p<0.0001)$ in patients group with high NK \% (>17.5\%). Lower, also significant correlation, was observed in patients with NK \% between 15 and $17.5 \%$ $(r=0.121, p=0.0155)$. The absence of NK \%-NKc correlation was observed in the patients groups with following NK \% (12-15\%), (12-10\%), (10-8 \%) and (8-7.3\%). However, strong correlation between NK \%-NKc re-appears in the groups of patients with NK levels $<7.3 \%(7.3-6.3)$ and (1.7-6.3 \%) $(r=0.269, \mathrm{p}<<0.0001)$ (Fig. 2, B).

Thus, we detected that NK\%-NKc correlation depends on NK levels status. Here, we showed that variation in quality status of NK population plays an important role in correlative association with their cytotoxic activity. Thus, quantitative changes within accentuated zones affect the quality of associative character in NK\%-NKc and its impact on clinical outcomes.

NK frequency and NK cytotoxicity are significant parameters that determine clinical outcomes. Recently, several independent groups showed that individuals with elevated NK lymphocytes levels and NK cytotoxicity have lower risk and better clinical outcome in case of viral infections and oncology diseases compared to patients with lower NK \% and NKc levels [25, 26, 28, 30]. A growing number of data [1, 3, 8, 35] suggest a link between abnormal NK \% and NKc and reproductive failure.

Despite these results a question still remains: which are the normal (optimum) levels of NK? An additional layer of complexity come from the fact that NK \% varies dependently on gender, ethnical, and racial backgrounds [2, 6, 11, 27, 33]. NK \% and NKc levels is increased in males compared to females. This difference is significant in a reproductive age. These differences become less pronounced in females over 40. [7, 16], while NK \% and NKc levels are markedly decreased in pregnant women. That is why, NK system attracts special interest in the field of immunology of reproduction. It is accepted that NK cells play a critical yet poorly defined role in reproductive processes such as implantation, trophoblast invasion, and spiral artery remodeling [23]. An elevated NK cell frequency [1, 35], cytotoxicity [24], and imbalance between inhibitory and activating receptor expression on NK cells $[3,5,12,14]$ are each associated with different reproductive failures. Several groups proposed to define "reproductive normal values" of NK frequency $[1,8,18]$. Following values were suggested as reference points $<12 \%,<15 \%$ or $<18 \%$, respectively, as favorable values for implantation and normal pregnancy outcome. In contrast, elevated NK counts were suggested as indicators of increased risk of reproductive failure in women.

ISSN 1996-4536 (print) • ISSN 2311-0783 (on-line) • Біологічні Студії / Studia Biologica • 2019 • Том 13/№2 • С. 11-20 

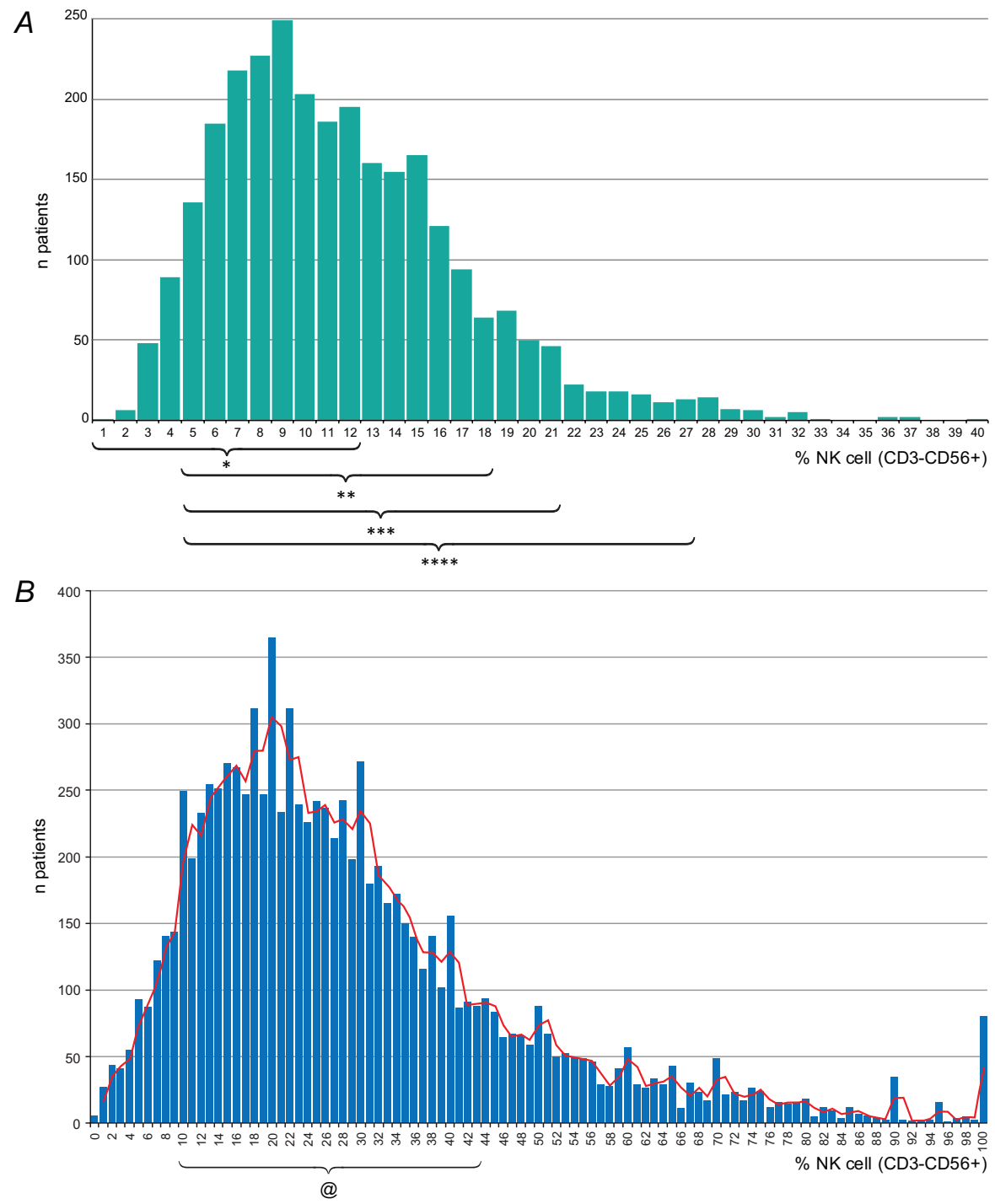

Fig. 1. Distribution of number of natural killer lymphocytes $(A)$ and natural killer cytotoxicity $(B)$ in patients groups:. $A$ - natural killer (CD56+CD3-) cells \% from all lymphocytes $(n=2,804)$; $B$ - natural killer cytotoxicity (E/T 15/1) was measured by FC natural killer assay against K562 $(n=9,535)$.

${ }^{*}$ - normal value for pregnancy prognosis [1]; ${ }^{* *}-$ normal value for pregnancy prognosis $[8,18]$; ${ }^{* *}$ -

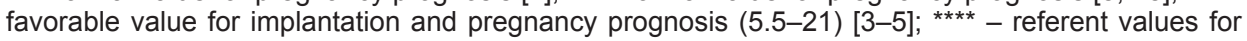
young caucasian women (4.8-26.1\%) [16, 27]; @ - favorable value of our laboratory for implantation and pregnancy prognosis (12.5-41\%) [3-5]

Рис. 1. Розподіл рівнів природних кілерних лімфоцитів $(A)$ і цитотоксичної активності природних кілерних лімфоцитів (B) серед пацієнтів: $A$ - кількість природних кілерів як \% (CD56+CD3-) клітин від усіх лімфоцитів ( $n=2804) ; B$ - цитотоксичність природних кілерів за співвідношення ефектор/мішень (15/1) визначали методом проточної цитометрії протипухлинної лінії K562 ( $n=9535)$.

* - оптимальні значення для успішного перебігу вагітності [1]; ** - оптимальні значення для успішного перебігу вагітності $[8,18]$; *** - оптимальні значення для імплантації ембріона й успішного перебігу вагітності $(5,5-21)$ [3-5]; ${ }^{* * *}$ - рефрерентні межі для молодих здорових жінок $(4,8-$ $26,1 \%)[16,27] ;$ @ - оптимальні значення для імплантації ембріона й успішного перебігу вагітності $(12,5-41 \%)[3-5]$ 

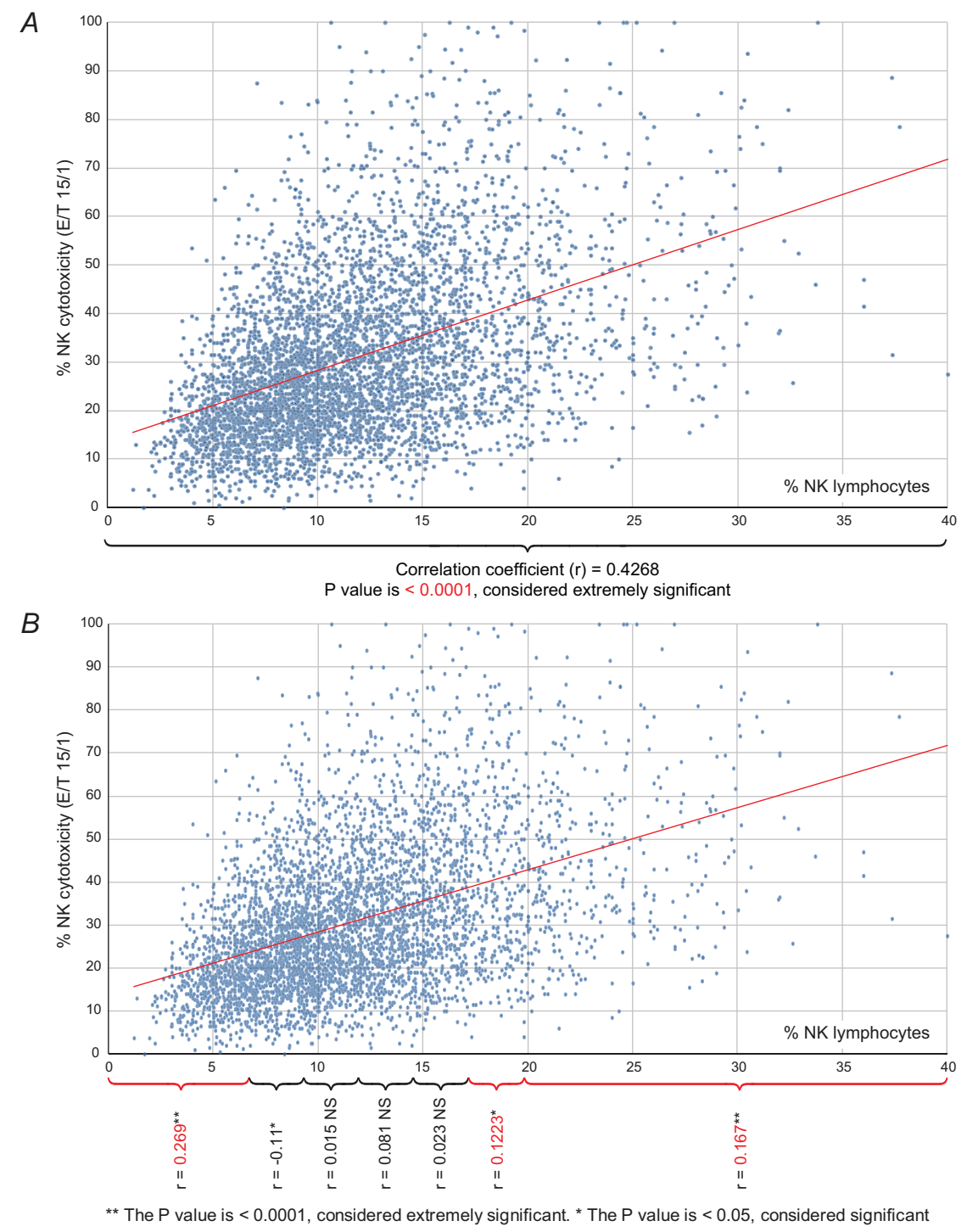

Fig. 2. Correlation between number and cytotoxic activity of NK in total population $(n=8,864)(A)$, and in separate zones divided according to number of NK $(B)$

Рис. 2. Кореляція між кількістю й цитотоксичною активністю природних кілерів у загальній популяції $(n=8864)(A)$ та в окремих зонах, поділених за кількістю природних кілерів $(B)$

Undoubtedly, the predictability of prognosis using NK frequency, as well as the role of elevated NK \% in reproductive outcome, are still under debate [31,32]. Many investigators agree that measurement of functional activity of NK cells is very important for clinical prognosis [34]. However, limited affordability, complexity and lack of standardization were the main reasons that this marker is still not a part of the routine clinical diagnostics. In contrast, characterization of NK phenotype markers is much easier and possesses comparable clinical utility. It was shown that misbalance between NK expression of KIR receptor or activation ligands is associated with reproduction failures [22, 31]. 
In this study, we demonstrated that different qualitative states of NK population have different correlative associations with cytotoxicity. The absence of correlation between NK \% and NK cytotoxicity was found in the moderate-to-normal zone of NK frequency. Thus, in these zone, counts of NK cells do not directly determine cytotoxicity. Instead, NK lymphocytes counts in the moderate-to-normal zone are sufficient and compatible with the generation of any NKc levels. Associations between NK \% and NKc is more quantitative. Within the balanced "normal" zone, level of NK cytotoxicity rather than NK frequency is determined by proportions of active subsets. This regulatory mechanism adjusts NKc to the actual (necessary) situation, reversing the role of the NK frequency in these zones. Here, in the "normal zone", NK numbers do not directly equate to NKc. In contrast, the accentuation of NK through inflammation-affectation results in decreased/increased NK numbers and deregulation of the clonal population balance. Affectation of regulatory mechanisms results in a direct impact of NK frequency on cytotoxicity. Thus, quality directly determines functional quantity. Therefore, it is possible that increase or decrease in NK frequency is regulated mostly by proportions of cytotoxic NK subsets.

Increased NK \% and NKc is the first unfavorable accentuation marker displayed during reproductive development [1]. Previously, we showed that some accentuations have negative predictive value for implantation and pregnancy outcome. A majority of those outcomes were associated with NK surface markers expression and their activity and among them, NK accentuations possess bilateral features. A decreased as well as an increased CD8, CD158 expression and CD69 activation proved to be predictive of the negative clinical outcome [10-14]. In contrast, in the case of T-lymphocytes - negative predictive markers were increased (HLADR, CD56, CD158) or decreased (CD4 levels) [3-5].

\section{CONCLUSION}

Reproductive disturbances of the immune genesis are not often accredited to general clinical status, but rather a situational combination of adverse immunological - physiologically - genetic factors. Therefore, it is not always true that the genetic mother-fetus combination and the functional state of a female patient are independent predictive markers of unfavorable outcome. Thus, fertility can only be confirmed by the onset of pregnancy and carrying of pregnancy in the given cycle instead of the normal range of different parts of the immune and endocrine systems. The fact that the NK percentage is gaining a new role when passing a certain threshold might help to determine the physiologicallybalanced standard range for specific clinical groups. Our study demonstrates that knowing this range might help to create a more favorable corridor for a course of pregnancy.

1. Beer A.E., Kwak J.Y., Ruiz J.E. Immunophenotypic profiles of peripheral blood lymphocytes in women with recurrent pregnancy losses and in infertile women with multiple failed in vitro fertilization cycles. Am J Reprod Immunol, 1996; 35: 376-382. [PMID:8739457]

2. Bisset L.R., Lung T.L., Kaelin M., Ludwig E., Dubs R.W. Reference values for peripheral blood lymphocyte phenotypes applicable to the healthy adult population in Switzerland. Eur J Haematol, 2004; 72(3): 203-12.

[DOI: https://doi.org/10.1046/j.0902-4441.2003.00199.x; PMID:14962239]

3. Chernyshov V.P., Sudoma I.O., Dons'koi B.V., Kostyuchyk A.A., Masliy Y.V. Elevated NK cell cytotoxicity, CD158a expression in NK cells and activated T lymphocytes in peripheral blood of women with IVF failures. Am J Reprod Immunol, 2010; 64: 58-67.

[DOI: https://doi.org/10.1111/j.1600-0897.2010.00825.x; PMID:20236262]

ISSN 1996-4536 (print) • ISSN 2311-0783 (on-line) • Біологічні Студії / Studia Biologica • 2019 • Том 13/№2 • C. 11-20 
4. Chernyshov V.P., Dons'koi B.V., Sudoma I.O., Goncharova Y.O. Favorable immune phenotype predicts successful implantation and pregnancy. Immunol Lett, 2014;162(2 Pt B): 217-21. [DOI: https://doi.org/10.1016/j.imlet.2014.10.022; PMID:25445617]

5. Chernyshov V.P., Dons'koi B.V., Sudoma I.O., Goncharova Y.O. Multiple immune deviations predictive for IVF failure as possible markers for IVIG therapy. Immunol Lett, 2016; 176: 44-50. [DOI: https://doi.org/10.1016/j.imlet.2015.12.010; PMID:27233364]

6. Choi J., Lee S.J., Lee Y.A., Maeng H.G., Lee J.K., Kang Y.W. Reference values for peripheral blood lymphocyte subsets in a healthy korean population. Immune Netw, 2014; 14(6): 289-95. [DOI: https://doi.org/10.4110/in.2014.14.6.289; PMID:25550695; PMCID:PMC4275386]

7. Chung H.J., Park C.J., Lim J.H., Jang S., Chi H.S., Im H.J., Seo J.J. Establishment of a reference interval for natural killer cell activity through flow cytometry and its clinical application in the diagnosis of hemophagocytic lymphohistiocytosis. Int J Lab Hematol, 2010; 32(2): 239-47. [DOI: https://doi.org/10.1111/j.1751-553X.2009.01177.x; PMID:19614711]

8. Coulam C.B., Goodman C. Increased pregnancy rates after IVF/ET with intravenous immunoglobulin treatment in women with elevated circulating C56+ cells. Early Pregnancy, 2000; 4(2): 90-8. [PMID:11723539]

9. Di Santo J.P. Natural killer cell developmental pathways: a question of balance. Annu Rev Immunol, 2006; 24: 257-286.

[DOI: https://doi.org/10.1146/annurev.immunol.24.021605.090700; PMID:16551250]

10. Dons'koi B.V., Chernyshov V.P., Osypchuk D.V. Measurement of NK activity in whole blood by the CD69 up-regulation after co-incubation with K562, comparison with NK cytotoxicity assays and CD107a degranulation assay. J Immunol Methods, 2011; 30: 187-195. [DOI: https://doi.org/10.1016/j.jim.2011.07.016; PMID:21839083]

11. DonskoI B.V., Chernyshov V.P., Osypchuk D.V. The immunophenotypic characteristics of two functionally different natural killer cell subpopulations in peripheral human blood. Fiziol Zh, 2011; 57: 29-35.

[PMID:21516831]

12. Dons'kol B.V., Chernyshov V.P., Sudoma I.O., Honcharova I.O., Osypchuk D.V. Qualitative analysis of accented CD158a receptor expression in NK-lymphocytes in women with reproductive failures. Lik Sprava, 2013; (1): 86-93.

[PMID:23951916]

13. Dons'koi B.V., Chernyshov V.P., Sirenko V.Y., Strelko G.V., Osypchuk D.V. Immunobiology. Peripheral blood natural killer cells activation status determined by CD69 upregulation predicts implantation outcome in IVF. Immunobiology, 2014; 219: 167-71.

[DOI: https://doi.org/10.1016/j.imbio.2013.09.002; PMID:24157280]

14. Dons'koi B.V. Accentuated hypo- and hyper-NK lymphocyte CD8 expression is a marker of NK subsets' misbalance and is predictive for reproductive failures. Immunobiology, 2015; 220(5): 649-55.

[DOI: https://doi.org/10.1016/j.imbio.2014.11.015; PMID:25576428]

15. Golden-Mason L., Cox A.L., Randall J.A., Cheng L., Rosen H.R. Increased natural killer cell cytotoxicity and NKp30 expression protects against hepatitis $C$ virus infection in high-risk individuals and inhibits replication in vitro. Hepatology, 2010; 52(5): 1581-9.

[DOI: https://doi.org/10.1002/hep.23896; PMID:20812318; PMCID:PMC2967665]

16. Jentsch-Ullrich K., Koenigsmann M., Mohren M., Franke A. Lymphocyte subsets' reference ranges in an age- and gender-balanced population of 100 healthy adults - a monocentric German study. Clin Immunol, 2005; 116(2): 192-7.

[DOI: https://doi.org/10.1016/j.clim.2005.03.020; PMID:15993366]

17. Kane K.L., Ashton F.A., Schmitz J.L., Folds J.D. Determination of natural killer cell function by flow cytometry. Clin Diagn Lab Immunol, 1996; 3(3): 295-300. [PMID:8705672; PMCID:PMC170335]

18. Karami N., Boroujerdnia M.G., Nikbakht R., Khodadadi A. Enhancement of peripheral blood CD56(dim) cell and NK cell cytotoxicity in women with recurrent spontaneous abortion or in vitro fertilization failure. J Reprod Immunol, 2012; 95(1-2): 87-92.

[DOI: https://doi.org/10.1016/j.jri.2012.06.005; PMID:22854126]

ISSN 1996-4536 (print) • ISSN 2311-0783 (on-line) • Біологічні Студії / Studia Biologica • 2019 • Том 13/№2 • С. 11-20 
19. Knorr D., Bachanova V., Michael RV., Miller J.S. Clinical utility of natural killer cells in cancer therapy and transplantation. Semin Immunol, 2014; 26: 161-172.

[DOI: https://doi.org/10.1016/j.smim.2014.02.002; PMID:24618042; PMCID:PMC3984606]

20. Kutukculer N., Azarsiz E., Karaca N.E., Ulusoy E., Koturoglu G., Aksu G. A Clinical and Laboratory Approach to the Evaluation of Innate Immunity in Pediatric CVID Patients. Front Immunol, 2015; 27(6): 145.

[DOI: https://doi.org/10.3389/fimmu.2015.00145; PMID:25964782 PMCID:PMC4410606]

21. Lanier L.L. Natural killer cell receptor signaling. Curr Opin Immunol, 2003; 15: 308-14. [PMID:12787756]

22. Lee S.K., Na B.J., Kim J.Y., Hur S.E., Lee M., Gilman-Sachs A., Kwak-Kim J. Determination of clinical cellular immune markers in women with recurrent pregnancy loss. Am J Reprod Immunol, 2013; 70(5): 398-411.

[DOI: https://doi.org/10.1111/aji.12137; PMID:23656517]

23. Le Bouteiller P., El Costa H., Aguerre-Girr M., Tabiasco J. Immunity of pregnancy: novel concepts. Bull Acad Natl Med, 2009; 193: 1029-1041. [PMID:20120385]

24. Matsubayashi H., Hosaka T., Sugiyama Y., Suzuki T., Arai T., Kondo A., Sugi T., Izumi S., Makino T. Increased natural killer-cell activity is associated with infertile women. Am J Reprod Immunol, 2001; 46: 318-322.

[PMID:11712759]

25. Ogata K., An E., Shioi Y., Nakamura K., Luo S., Yokose N., Minami S., Dan K. Association between natural killer cell activity and infection in immunologically normal elderly people. Clin Exp Immunol, 2001; 124(3): 392-7.

[DOI:https://doi.org/10.1046/j.1365-2249.2001.01571.x;PMID:11472399;PMCID:PMC1906081]

26. Ogata K., Yokose N., Tamura H. Natural killer cells in the late decades of human life. Clin Immunol Immunopathol, 1997; 84: 269-75.

[DOI: https://doi.org/10.1006/clin.1997.4401; PMID:9281385]

27. Reichert T., DeBruyère M., Deneys V., Tötterman T., Lydyard P., Yuksel F., Chapel H., Jewell D., Van Hove L., Linden J. Lymphocyte subset reference ranges in adult Caucasians. Clin Immunol Immunopathol, 1991; 60(2): 190-208.

[DOI: https://doi.org/10.1016/0090-1229(91)90063-g; PMID:1712687]

28. Sansoni P., Cossarizza A., Brianti V. Lymphocyte subsets and natural killer cell activity in healthy old people and centenarians. Blood, 1993; 82: 2767-73.

[PMID:8219229]

29. Sun J.C., Lanier L.L. Natural killer cells remember: An evolutionary bridge between innate and adaptive immunity. Eur J Immunol, 2009; 39: 2059-2064.

[DOI: https://doi.org/10.1002/eji.200939435; PMID:19637199; PMCID:PMC2819266]

30. Sun C., Sun H.Y., Xiao W.H., Zhang C., Tian Z.G. Natural killer cell dysfunction in hepatocellular carcinoma and NK cell-based immunotherapy. Acta Pharmacol Sin, 2015, 36(10):1191-9. [DOI: https://doi.org/10.1038/aps.2015.41; PMID:26073325; PMCID:PMC4648180]

31. Thum M.Y., Bhaskaran S., Abdalla H.I., Ford B., Sumar N., Shehata H., Bansal A.S. An increase in the absolute count of CD56dimCD16+CD69+ NK cells in the peripheral blood is associated with a poorer IVF treatment and pregnancy outcome. Hum Reprod, 2004; 19(10): 2395-400. [DOI: https://doi.org/10.1093/humrep/deh378; PMID:15319390]

32. Thum M.Y., Bhaskaran S., Bansal A.S., Shehata H., Ford B., Sumar N., Abdalla H.I. Simple enumerations of peripheral blood natural killer (CD56+ NK) cells, B cells and T cells have no predictive value in IVF treatment outcome. Hum Reprod, 2005; 20(5): 1272-6. [DOI: https://doi.org/10.1093/humrep/deh774; PMID:15829490]

33. Torres A.J., Cisneiros P., Guedes R., Grassi M.F., Meyer R., Bendicho M.T., Lopes T.G., Félix G., Netto E.M., Brites C., Abe-Sandes K., Brandão C., Alcantara-Neves N., Freire S.M. Lymphocyte subset reference intervals in blood donors from northeastern. Brazil An Acad Bras Cienc, 2015; 87(2): 1019-25. [DOI: https://doi.org/10.1590/0001-3765201520130114; PMID:25923166]

ISSN 1996-4536 (print) • ISSN 2311-0783 (on-line) • Біологічні Студії / Studia Biologica • 2019 • Том 13/№2 • C. 11-20 
34. Whiteside T.L., Herberman R.B. Role of human natural killer cells in health and disease. Clin Diagn Lab Immunol, 1994; 1: 125-33. [PMID:7496932; PMCID:PMC368214]

35. Winger E.E., Reed J.L., Ashoush S., El-Toukhy T., Ahuja S., Taranissi M. Elevated Preconception CD56(+) 16(+) and/or Th1:Th2 Levels Predict Benefit from IVIG Therapy in Subfertile Women Undergoing IVF. Am J Reprod Immunol, 2011; 66: 394-403.

[DOI: https://doi.org/10.1111/j.1600-0897.2011.01018.x; PMID:21623994]

\section{КІЛЬКІСТЬ ПРИРОДНИХ КІЛЕРІВ НЕ ВИЗНАЧАЄ РІВНЯ ЇХньОї цИтотоксИчнОстІ}

Б. В. Донськой

ДУ Інститут педіатрії акушерства та гінекології НАМН України вул. Платона Майбороди, 8, Київ 04050, Україна

e-mail: boris_donskoy@ukr.net

Цитотоксичність природних кілерних лімфоцитів $€$ важливим фрізіологічним параметром стану імунної системи. Клінічна раціональність визначення цитотоксичності досі залишається дискутабельною, зокрема, через складність її визначення в рутинній лабораторній діагностиці. Ми провели дослідження цитотоксичності природних кілерів і вимірювання відсотка природних кілерних лімфоцитів серед 8864 пацієнток із неплідністю. Частка пацієнток із високою цитотоксичністю природних кілерів у загальній популяції була збільшена, особливо серед пацієнток із множинними репродуктивними втратами у минулому (41,6 \%), порівняно з пацієнтками із неускладненим анамнезом первинна неплідність $(24,4$ \%) і вторинна неплідність $(18,7$ \%). У загальній популяції відсоток природних кілерів достовірно корелював із цитотоксичністю $(r=0,426, p<0,0001)$, проте за розділення пацієнтів на групи відповідно до рівня природних кілерів кореляція повністю зникала в усіх групах із нормальною кількістю природних кілерів. Водночас серед пацієнток із акцентовано високою та низькою цитотоксичністю кореляція залишалася високо достовірною. Відсоток природних кілерів достовірно корелював із цитотоксичністю $(r=0,2021$, $p<0,0001)$ у пацієнток із високим відсотком природних кілерів (> 17,5 \%). У пацієнток із відсотком природних кілерів 15-17,5 \% кореляція була не така висока, проте достовірна $(r=0,1213, p=0,0155)$. Також достовірно високу кореляцію $(r=0,2689$, p < 0,0001) спостерігали у пацієнток із відсотком природних кілерів < 7 \% $(1,7-$ 7,3 \%), тоді як пацієнтки з відсотком 7,3-15 \% не мали достовірної корелятивної асоціації між відсотком природних кілерів і їхньою цитотоксичністю. Результати засвідчують неможливість прогнозування функціональної активності природних кілерних клітин у індивідуумів із нормальними рівнями природних кілерних лімфоцитів. За нормальної кількості природних кілерів їхній цитотоксичний прояв перебуває під регуляторним контролем, може генерувати актуально-необхідну цитотоксичну активність, тоді як за зниженого чи збільшеного рівня природних кілерних лімфоцитів регуляторні механізми не здатні компенсувати акцентуацію. Отже, акцентуація має самостійний незалежний безпосередній вплив на функціональну активність.

Ключові слова: природні кілери, цитотоксичність, імунні акцентуації, невдача імплантації ембріна, невиношування вагітності

Одержано: 30.09.2019

ISSN 1996-4536 (print) •ISSN 2311-0783 (on-line) • Біологічні Студії / Studia Biologica • 2019 • Том 13/№2 • C. 11-20 